2010

\title{
Book Review: The Joy of Teaching: Effective Strategies for the Classroom
}

Amy Lynn Dee

George Fox University, adee@georgefox.edu

Follow this and additional works at: https://digitalcommons.georgefox.edu/soe_faculty

Part of the Education Commons

\section{Recommended Citation}

Dee, Amy Lynn, "Book Review: The Joy of Teaching: Effective Strategies for the Classroom" (2010). Faculty Publications - School of Education. 205.

https://digitalcommons.georgefox.edu/soe_faculty/205 
Reviewed by Amy Dee, George Fox University, Newberg, Oregon

The Joy of Teaching: Effective Strategies for the Classroom,

\author{
by Harry Hazel. Eugene, Oregon: Wipf and Stock, 2010, 145 pages,
}

ISBN 978-1606086131

Woven throughout his book, the joy Hazel found in the vocation of teaching rises above all other content, ergo the title. Hazel begins in the first chapter with the joy and the rewards of teaching by observing that our call to teach provides a means toward self-actualization as well as a way to serve God's people. Many enter the field of teaching with hearts and minds centered on care for others as well as a desire to make a difference in the lives of students. Through many of the over one hundred stories collected during the research for this book, Hazel speaks to the inherent joy many teachers find as the most compelling reason to remain in education. Regardless of the age level taught, the teachers' stories in Hazel's book expose the intrinsic rewards of the vocation as an essential reason we have responded to the invitation to serve as educators.

On a continuum between Parker Palmer and Harry Wong, Hazel's book lands closer to Wong, and even though Hazel hopes to speak to a broad and inclusive audience, the content suits those in higher education much more than PK-12 faculty. Upon first reading of the title, the book appears to address management or pedagogical strategies for the general elementary or secondary classroom - the subtitle Effective Strategies for the Classroom- suggests as much; however, the reader soon discovers Hazel's affinity for higher education and his role as a professor concerned with service and care, who has hints for those new to academia. Readers will find that the book begins rather like Palmer, albeit with a much lighter emotional affect, and then quickly shifts to brief commentary on several common challenges such as what one would find in Wong.

Punctuated by anecdotes and quotations, the topics to which Hazel attends include finding joy in the vocation of teaching, delivering captivating lectures, motivating students, disciplining students, writing papers, enhancing speaking skills and managing time. In his attempt to give new professors or teachers collegial advice, or to pass on accumulated wisdom to the next generation of educators, Hazel skims the surface of topics to which tomes are often devoted. For example, the section on motivating teenagers amounts to two paragraphs. Additionally, Hazel reinforces the importance of providing students with useful and timely feedback, but neglects to coach or suggest specific methods for making feedback meaningful. Chapter 6 provides an overview of writing for professors and students, consisting of organizational suggestions and checklist for making revisions. Again, volumes are available for those needing assistance in any of the areas in which Hazel offers counsel. Some will find the advice within this book brief and functional, while others will read the passages as prosaic.

Evidence of the book's tendency to speak predominately to university professors emerges clearly in the chapter dedicated to teaching methods. Hazel acknowledges the lecture as the principal process by which content passes from professor to student. In the current culture of constructivist, or studentcentered learning, the reality of the lecture as dominant might not sit well with some readers; but nonetheless, the lecture prevails in all institutions, hence the legitimate need for the material Hazel offers. A new professor certainly understands the need to prepare, but the addition of human-interest elements to an otherwise banal topic can elevate the lecture and perhaps even change the perception 
the student has toward the subject. By including such important aspects such as drama, humor, eye contact and the avoidance of abstraction, Hazel imparts the best of advice for the delivery of lectures students remember. Now, if we could just get them to read the text.

A well written and easy read, the book offers another glance at a broad range of topics in a thumbnail style that will appeal to those seeking either a quick pickup after a challenging day in the classroom, or a brief overview of some ways to improve teaching strategies. For those new to a professorial post, or for someone without the support of collegial chat in the hallway, the book offers friendly advice in a passing manner. Hazel has attempted to offer collected wisdom from years in a complex and multifaceted profession. Teacher mentors and academic resource centers will want a copy, but most readers desire more depth on a single subject in a book. As the French say, nous avons encore du pain sur la planche, meaning we actually have a lot of bread on the table, in fact, maybe too much. 